\title{
Reframing in Conflict Mediation: Empowering Parties or Manipulating Decision-Making?
}

\author{
Syaiful Anam ${ }^{1}$, Rezki Satris ${ }^{2}$ \\ 'Universitas Mataram, Nusa Tenggara Barat \\ ${ }^{2}$ Universitas AMIKOM Yogyakarta \\ Email: s.anam@unram.ac.id Email: rezki@amikom.ac.id
}

\begin{abstract}
Abstrak
Artikel ini bertujuan untuk menjelaskan bagaimana mengkonstruksikan kembali bentuk mediasi melalui suatu analisis framing. Konsep framing dalam sebuah mediasi adalah sebuah bentuk komunikasi yang dibingkai secara konstruktif. Dalam dinamika konflik, proses mediasi menjadi bagian yang paling menentukan dalam proses pemecahan masalah. Bagaimana seorang mediator mampu membingkai ulang konsep mediasi ini dengan memberdayakan pihak-pihak yang berkonflik untuk dapat keluar dari masalah tanpa harus memperburuk situasi. Adapun metode yang digunakan dalam penulisan ini adalah bersifat kualitatif dengan pendekatan sebuah analisis freming yang menjelaskan bahwa seorang mediator bukanlah pengambil keputusan dari proses negosiasi, akan tetapi seorang mediator mampu mencari solusi terhadap permasalahan yang bersifat konstruktif dan kooperatif sesuai dengan kemampuan mediator.
\end{abstract}

Kata Kunci: Framing, Konflik, Mediasi, Pengambilan Keputusan

\begin{abstract}
This study aims to explain how to reconstruct the form of mediation through a framing analysis. the concept of framing in negotiation is a form of constructively framed communication. the dynamics of conflict, the mediation process, become the most decisive part of the problem-solving process and how a mediator can reframe the mediation concept by empowering conflicting parties without worsening the situation. the research method used qualitative with a framing analysis approach. It explains that a mediator is not a decisionmaker in the negotiation process. A mediator can find solutions to constructive
\end{abstract}


and cooperative problems following the mediator's abilities.

Keywords: Framing, Conflict, Mediation, Decision Making

\section{INTRODUCTION}

One of the beneficial skills that have to be mastered by mediators is the technique of reframing. Reframing here refers to the communication skill utilized by the mediator to change the parties' thoughts to a more affirmative meaning to support parties in gaining resolution (Mayer, 2000:132). in other words, reframing means to shift the frame that is fabricated by parties to describe the problem or conflict into another more constructive frame.

Given the importance of the skill in determining the settlement in a mediation process, this paper will examine whether reframing skills could empower parties. It eventually brings them to an agreement, or rather this skill is a form of manipulating the issues and decisions conducted by a mediator, which might consequently exacerbate the dispute. It will argue that reframing can be regarded as both empowering parties and manipulating choices in mediation. Empowering parties means that the mediator uses his/her communication skills to support parties in finding ways to resolve (Sharland, 2007) by reframing the negative frame delivered by parties. Whereas manipulation here refers to, using the Robert Benjamin's term (1995), as a positive deception that could encourage parties to gain a resolution as well, despite the potential risks that might be counterproductive with the principle of mediation itself.

This paper, thus, will be divided into four parts to substantiate the argument. the first part will be discussing the reframing skill in general and as well as its application in the process of mediation. the idea of this part is to explore what is reframing itself in general, including its purposes and methods. the next section will be analyzing the concept of empowerment in mediation. It will then have an elaboration through the discussion of reframing. Afterward, it will be discussing on how reframing is in a more negative term as a form of manipulating decisionmaking. It will explain whether or not reframing is genuinely a form 
of deception. the last part of the paper will then conclude that while reframing could empower parties to reach an agreement, it is also manipulative in specific ways.

\section{RESULT AND EXPLANATION}

Reframing in Mediation: General Introduction

The mediator needs to have competence or skill of communication when dealing with parties in conflict or dispute. By having specific knowledge of communication and the ability to use it in the mediation process, it could facilitate parties to progress and to reach an agreement. For instance, when dealing with an interpersonal dispute such as a divorce dispute, the mediator should understand how the emotion of parties when responding to issues related to divorce. in this situation, what mediator should do is that he/she has to utilize his/ her communication strategy in facilitating parties to get accurate and positive information exchange among them. Failure conversely creates a tough situation in which parties insist upon their position due to the unclear information delivered by the mediator. Hence, the agreement is consequently challenging to reach (Donohue, Allen \& Burrell, 1985: 76-77).

'Reframing' is one of the communication skills that equip mediator in facilitating parties. It is perceived as crucial since the mediator in the mediation process frequently encounters a situation in which parties came with their frame of interpretation to describe or to behave in the dispute they are involving. the concept of 'frame or framing' itself has been offered by Bateson (1972) to refer to a psychological idea where conversations or social actions have a construction within restricted meaning based on the interpretation of each party. It is as a result, including particular messages and disregarding others (Benjamin \& Irving, 2005:478; Bodtker \& Jameson, 1997:238). These frames might consequently not only create misinterpretation and misunderstanding by the other party but also make each party remain to insist upon their position that might bring the mediation to an uncomfortable atmosphere. Hence, the mediator in this circumstance should 'reframe' the statements that tend to be misunderstood by or to insult other parties into a new frame containing neutral or positive meanings. 
Tracing back the historical experiences, the technique of reframing is not new in human history. in dealing with their internal conflict, for instance, humans frequently and automatically reframe specific issues that have put them in a complicated situation into a frame that make them feel better. When encountered with the problem of losing someone who they are loved, individuals would tend to think, "I am sure she wouldn't have wanted me to cry or be sad if she were here." This kind of reframing is simple yet successfully to convince the reframer that they could still "move on" and do not occupy their sorrow (Zaffar, 2008).

The application of reframing strategy in current practice has been developed well and is in a particular situation. the method of reframing conducted by a psychiatrist, Milton H. Erickson, shows that reframing can create significant changes in the thought and behavior of the patient. Erickson encountered a problem where his patient, a teacher, and a pious Catholic, were feeling under pressure because of her bad behavior that frequently passes her flatus loudly in her teaching activity in the classroom. She then locked herself in her room, avoiding interaction with the people around her. in this situation, Erickson constructed a new frame for his patient by saying (Rosen, 1974, in Zaffar, 2008),

"You say that you are a good Catholic. Then why do you insult the Lord; why do you make a mockery of him? You ought to be ashamed of yourself - making a mockery of God and calling yourself a good Catholic." Erickson continued to state, "II] hauled out my anatomy book, an atlas showing all the illustrations of the body. I showed her a cross-section of the rectum and anal sphincter. I said, 'Now, man is very skillful at building things. But, can you imagine a man being sufficiently skillful at building a valve that contains solid matter, liquid matter, and air- and emits downward only the air?' I said, 'God did. Why don't you respect God?’”

At the final stage, Erickson suggested a behavioral prescription towards his patient. As restated by Zaffar (2008), "He ordered her to eat some baked beans flavored by garlic and onions (a great stimulant for the colon) and then dance around her apartment naked, "emitting loud ones, soft ones, big ones, little ones ... and enjoy God's work." Finally, that woman had successfully overcome her problem and involved in any social activities. This experience showed how Erickson shifted the 
underlying frame of his patient by using her religious worldview as a way to justify her awkwardness and turn it as an acceptable matter in social life.

Through the example experienced by Erickson, the purpose of reframing is to shift the context situation faced by a patient to another better context. This technique, as stated by Zaffar (2008), is called "Reframing by Recontextualization." It is how a new frame/context created through the previously factual background of the patient itself (religious belief, or socio-economic status). Despite changing into a modern context, reframing is also to persuade parties, that is, moving out from the current circumstance and status quo. Here, the mediator helps parties to open their minds upon a higher possibility of achieving settlement in the future by exploring parties' creative solutions.

There are many ways to do reframing in dispute. For instance, Fisher and Ury (1991) suggested the technique of "agree to disagree." Mediator using this technique to facilitate people intolerant with homosexuality, for example, is likely challenging to persuade them, and they believe in that position into a change after mediation. the mediator should try to convince parties to the point that might be able to realize them upon the different believe they have, yet it is not to falsify the belief. Instead, it focuses on finding the core mutual values that might assist parties in reaching an agreement. Nevertheless, the use of this technique is widespread in mediation. It, too, focuses on values on future problems instead of the immediate one.

Another method that is more practical in reframing conflict is, as advocated by Jennifer Fisher, Coben \& Love, the practice of rituals and symbols. By bringing foods, drinks, and eating together at the same table will much reduce the level of tension between disputants and create a comfortable atmosphere so that they could be more cooperative. Also, a technique such as active listening is necessary to reframe conflict. Active listening requires mediator not only to listen carefully and actively but also to give a constructive reflection of his/her thoughts in responding to parties' issues without making any judgments. This constructive thinks that permeates into the words, sentences, and conversation done by the mediator is used to reframe the specific problems that might bring positive meaning to parties and ignore other issues that might 
negatively affect the mediation and parties (Phillips, 1999: 170).

Furthermore, reframing is also a tool to exercise the mediator's power in intervening parties. Intervention here means that the mediator uses his/her ability to reshape the structure or content of language, proposal, discourse, or utterance delivered by parties. It is a part of evaluation towards the appropriateness of parties' recommendations whether or not it will bring a solution to the dispute. Intervention through reframing moreover functions to provide alternatives to parties and bring them to a single shared-view perspective in which common elements of their proposal are reconstructed by mediator so that it will help parties to achieve mutual understanding and desirable solution. By doing useful reframing, it will change the way conflict being represented by parties through language and discourse into a constructive discussion (Donohue, Allen, \& Burrell, 1985:80; Gerami, 2009:443).

\section{Reframing: Empowering Parties}

One of the underlying purposes of mediation is to empower parties, meaning that through mediation, practice parties initially unable to find a way to solve the dispute are facilitated and supported in finding and developing their solution to settle their dispute. Cobb (1993) asserts that mediation is to empower parties, and Mayer (2000) has argued that the essence of mediation itself is to provide an empowering approach to solve serious conflict and dispute. This part of the paper then attempts to investigate whether the practice of reframing by the mediator is empowering parties and supporting the mediation process as a means to facilitate parties to achieve resolution.

To understand and determine whether reframing is a form of empowering parties, it will be necessary first to discuss the concept of empowerment in mediation. Many authors, researchers, and practitioners in mediation agree that 'empowerment' is an important aspect of mediation. However, there is no single agreedupon what exactly the concept is (O'Reardon, 2011), and it is indeed an ambiguous and indefinable concept (Sharland, 2007). Apart from that matter, empowerment itself is the core principle within the philosophy of mediation, and this is one of the reasons why mediation is a global method of dispute/ 
conflict resolution in various sectors (Doherty \& Guyler, 2008: 173).

The essence of empowerment in mediation is an attempt at supporting parties through certain strategies conducted by a mediator to facilitate parties to find their way to reach an agreement. It is as emphasized by Cobb (1997) that " ... empowered parties experience increased self-esteem, improved control over decision making, an increased sense of their power, and the reduction of painful emotions". What Cobb has stressed reflects that empowerment is precisely one of the core functions of mediation, that is, to merely facilitate parties to solve their dispute in their ways in a constructive manner. As the dispute that emerged from the parties' interactions, the mediator only functions to guide and facilitate them in which there should be a solution to the dispute from the disputants or parties' initiatives. Doherty and Guyler (2008) point out factors that make empowerment rests within the process of mediation, such as the decision to involve in mediation is based on the parties' decision without any coercion from any other people. Parties themselves determine the issues and topics discussed in mediation. Parties decide the decision and the content of agreement without any intervention from the mediator. the faithfulness of the agreement is up to the disputants or parties themselves (2008:173). These factors clearly show a simple set for and by the conflicting parties, and they accordingly need to be empowered throughout the mediation process so that there should be desirable solutions.

Why parties need to be empowered and how by empowering parties in mediation might help them to find the solution upon their dispute could also be well understood by exploring the main aspect of the empowerment itself. O'Reardon (2011) pointed out three important aspects of empowerment: cognitive, linguistic, and emotional. the cognitive aspect in empowerment describes the persons' ability to see new alternatives or choices that they did not see beforehand. It does not mean that the persons do not have the choices or options before, but it gives persons a new perspective in seeing that they have choices to solve their problem and dispute. in another way, it also constructs a person's belief and gives awareness upon a new believer or norm. For instance, a person who believes that persons from certain ethnicities, says ethnic $B$, is rude. It would influence 
someone's behavior in interacting and interpretation in seeing the problem. the critical question is whether or not these beliefs could help us to find ways of solving the problem. Empowerments then function to reshape this belief to a new belief that is more constructive in seeing the relationship.

The aspect of linguistic in empowerment means that empowerment could help a person to provide a new language to express self-feeling. Imagine that if we could only express the feeling of down and low by 'sad, it will make us see that all emotional feeling is only described by the word 'sad.' the consequence of it is that it would difficult to address the deep source of emotion specifically. It would be different if we could have words such as 'depressed,' 'melancholy,' 'disaffected,' and 'alienated,' which through these words could reflect a specific source of the emotion and enable us to respond properly. Empowerment thus helps the person to express feelings and emotions through languages.

The last aspect is emotional. in expressing their emotion, disempowered people do not know how to express it and tend to behave in unhealthy ways appropriately. in a discussion or mediation, a disempowered party does not know how to choose the right decision, being aggressive, or do not focus on the core problem of dispute. Empowerment enables disempowered parties to manage their emotion appropriately. Thus, this emotion could be more positively and productively.

With the discussion of the empowerment above, the essence of mediation itself is to empower parties. of course, for enabling parties, the mediator needs to develop and utilize specific skills and strategies. They are the main topics of the paper, 'Does reframing skill and strategy empower parties?'

It will argue that reframing is a skill that serves to empower parties in mediation. the idea of empowerment, as discussed above, is enabling parties that they are authorized or encouraged through specific skills and strategies of the mediator to find and explore their potential personal capacity for solving their problem and eventually reaching an agreeable solution. Reframing accordingly, as argued by Mayer (2000), functions to empower parties throughout its practices and principles. Livingood (2002) points out some reasons for using reframing in mediation to illuminate the empowering aspect 
of reframing, and these reasons reflect the tradition and policy of reframing as a way of empowering disputants/parties. Firstly, through reframing, a mediator can help parties to understand, and clarifying issues reviewed. By reframing, a mediator may help parties to narrow the complex problems and guide them in determining the essence of the problem. As suggested by Livingood, reframing statements from parties means clarify which issues to include in the process of mediation or by asking parties questions leading them to reframe their original statements. For example:

"Original Statement: "Our members are highly skilled and deserve to be paid for their skills."

"Request to Frame: "Are you saying that all your members are highly skilled and all deserve higher pay?"

"Reframed statement: Our mechanics and technicians are the ones I am talking about; they deserve higher rates." (Livingood, 2002: 45).

The example of reframing above shows that the mediator asks questions to a party so that the issue becomes narrower and help the party to identify his underlying interests. Furthermore, it might also open parties' minds and perspectives to think constructively in responding to their problems.

Secondly, reframing may create a new alternative perspective. By proposing a new alternative so that an old viewpoint can change. Parties are to see and understand the issues through a different light. It can be by using neutral or positive language and statements. Reframing through proper and positive communication might persuade parties to avoid certain words and comments that might trigger other parties' emotions and make them listen to their statements or their opponent. By hearing and understanding each proposal and issue through positive feedback, it would make parties think about their issue more constructively.

There are many more reasons to show that reframing is a form of empowering parties, but this will be the last point here, that is, by reframing it will assist parties to obtain their common problems and goals. Mayer (2000) and Livingood (2002) outline through their work that by reframing parties' paradigm and worldview also helps them to see not only the issues but also their position within the conflict system they have built through different light and perspective. the mediator 
needs to engage parties to change their storyline, alter their dramatic view of the conflict, hear each other, and encourage parties to work together in establishing commonshared story taken from their every element of the story. Then, they could find their common problems and goals (Mayer, 2000: 137-138; Livingood, 2002:48). It eventually will bring parties to be cooperative and help them to reach an acceptable agreement.

\section{Reframing and its manipulative aspect}

Despite its function to empower parties, reframing also serves as to manipulate parties. Some authors, such as Bernard Mayer, James Coben, Lela P. Love, and Robert Benjamin, acknowledge the manipulative aspect of reframing practice. For instance, Mayer (2000) argued that “...reframing can also be manipulative. It can be for people to talk out of their concerns or feelings or to water down a conflict or an issue" (2000: 139). Likewise, Coben and Love contend that mediator frequently uses reframing as manipulation and deception so that parties could consider issues and proposals through different perspectives, and that could promote settlement (in Coben, 2000: 4; and Coben \& Love,
2010: 20). Benjamin (1995), also considered that reframing in the form of deception could "...create an opportunity for the disputants' current unproductive worldviews to discard so that newer and more productive frames can emerge" (in Blanciak, 2002).

While reframing as manipulating parties' decisions and issues are common in the practice of mediation as to some extent it could foster the settlement, it is not recommended by some authors and practitioners in the field to frequently apply it. Benjamin (1995), a proponent of manipulative reframing, argues, as restated by Blanciak (2002), in a complicated situation, utilizing logic and reason is unlikely to convince parties to move out of their position. It is, therefore, by reframing in a manipulative way justified as an attempt to help parties in finding a solution. Instead of using the term 'manipulative,' the word 'deception' is seen to be more appropriate for Benjamin to describe this matter. the deception through reframing in Benjamin's account requires a mediator to sync with the worldview of each party. Mediator then should accept the "truth" of this worldview and use it to reframe the context. For Benjamin, this is "tricky ... 
because the mediator must be able to synchronize with each party's construction of reality in a manner that does not appear to invalidate any other party to the dispute". Adding Benjamin's account, Blanciak (2002) argues, "The deception involves the mediator working in a very indirect manner so as not to make a rational argument but to reframe." Moreover, Blanciak describes how Benjamin claimed to reframe as productive deception to resolution.

"Benjamin gives an example of reframing a dispute between parties who are actively fighting. First, he joins their worldview by complementing them "on how well they fight."He then continues by reframing the fighting into something positive. He tells them that "people who fight well can negotiate well." This technique is similar to what the deceptive trickster does in "twist[ing] their words and shift [ing] the context of the discussion" to a more productive frame. He continues in stating that "[r]eframing provides a technique by which resistance can be surreptitiously bypassed."

The goal of all of this is for the mediator "to reposition each of the antagonists so that the dispute is amenable to a resolution."

Taking the same position as Benjamin, Matthews (2011) has also argued that manipulation in reframing can always be allowed as long as it is applied at the right time and for a definite end. He emphasizes that there is no something wrong to be manipulative as the aim of it is to stop parties to regard themselves as internally bad and to help them in enhancing their capacity to solve a problem through their creative solutions (2011: 2).

However, authors such as Mayer, Coben, and Love have informed that this strategy (manipulative/ deception) might work to bring parties into an agreement and to give parties different perspectives in seeing their proposal. It may bring many risks to the parties and mediator as well. Mayer (2000: 139) has argued that "Manipulative reframing leads to disputants' mistrust of the process of resolution and of the third parties who are involved." Similarly, Coben and Love stress the risk of manipulative reframing by arguing that, "A major concern is a possibility that sophisticated mediation consumers are more «immune» to these types of mediator moves than are onetime participants" (2010: 20).

\section{CONCLUSION}

The essence of mediation is to empower parties. Empowering 
parties means that through mediation, parties are facilitated and helped to find their solution upon the dispute they are involving. A mediator is not the one that determines the decision-making and the agreement in the mediation. Instead, parties are encouraged constructively and cooperatively through their capacity and creativity. To establish a mediation process in which parties are working together constructively, the mediator needs specific skills in assisting his or her role. Reframing is one of the communication skills in mediation that should be mastered and utilized by a mediator. This paper argues that the principle and practice of reframing is similar to the mediation philosophy to empower parties.

Reframing enables parties in terms of its methods which assist parties to shift their negative frame, help them to obtain and explore their potential and capacity to create their accepted solution, and to engage them in fixing their relationship. All these matters are the principles of empowering parties advocated during the process of mediation. However, reframing can be in manipulative ways. the proponent of this technique argues that it is ethically justifiable as long as its goal is to help parties to find their capacity to achieve agreement. Nevertheless, some risks should be suggested by Mayer and Coben, that it might create distrust between parties, and it could make parties more 'immune' in particular cases.

\section{REFERENCES}

Benjamin, M \& Irving, HH 2005, "Using the "Mediatable Frame" to define the problem in mediating a parenting plan,' Conflict Resolution Quarterly, vol. 22, no. 4, pp. 473-491.

Benjamin, R 1995, 'The Constructive uses of deception: Skills, strategies, and techniques of the folkloric trickster figure and their application by mediators,' Mediation Quarterly, 13(1), pp.3-17.

Blanciak, P 2002, 'Reframing: the essence of mediation, online http://www.mediate.com/ articles/blanciak.cfm\#_ftn21, retrieved on 20 May 2013.

Bodtker, AM \& Jameson, JK 1997, 'Mediation as a mutual influence: Reexamining the use of framing and reframing, Mediation Quarterly, vol. 14, no. 3, pp. 237-249.

Cobb, S 1997, 'Empowerment and mediation: A Narrative perspective, Negotiation Journal 9:3, pp. 245-255. 
Coben, J 2000, 'Mediation's dirty little secret: Straight talks about mediator manipulation and deception,' Alternative Dispute Resolution Journal, pp.4-7

Coben, J \& Love, LP 2010, 'Trick or treat? the ethics of mediator manipulation', Dispute Resolution Magazine, Fall 2010, pp. 17-20.

Doherty, N \& Guyler, M 2008, 'The essential guide to workplace mediation and conflict resolution: Rebuilding working relationships,' India: Replika Press.

Donohue, WA, Allen, M \& Burrell, $\mathrm{N}$ 1985, 'Communication strategies in mediation,' in J. A. Lemmon (Ed.), 'Evaluative Criteria and Outcomes in Mediation,' Mediation Quarterly, no. 10. San Francisco: Jossey-Bass, pp. 75-89.

Gerami, A 2009, 'Bridging the theory and practice gap: Mediator power in practice, Conflict Resolution Quarterly, vol. 26, no. 4, pp.433-451.

Livingood, JM 2002, 'Reframing and its uses,' Dispute Resolution Journal; 57, 4, pp. 42- 59.

Matthews, C 2011, 'Manipulation the technique that dare not speak its name, online $\mathrm{ftp}: / /$
ftp.im.com.au/ME12/Final\%20 papers/Chris\%20Matthews. pdf. Retrieved on 20 May 2013.

Mayer, B 2000, 'The dynamics of conflict resolution: A practitioner's guide,' USA: John Wiley \& Sons.

O'Reardon, D 2011, 'What does "Empowerment" look like and how can mediators facilitate it?', online http://www.mediate. com/articles/oReardonD3. cfm\#bio, retrieved on 20 May 2013.

Phillips, B 1999, 'Reformulating dispute narratives through active listening, Mediation Quarterly, 17(2), pp.161-180.

Sharland, A 2007, 'The underlying philosophies of mediation: Empowerment,' online http://www. communicationand conflict. com/empowerment.html, retrieved on 20 May 2013.

Zaffar, E 2008, 'Context is King: A Practical Guide to Reframing in Mediation, online http://www. mediate.com/articles/zaffarE1. cfm\#5, retrieved on 20 May 2013. 